\title{
Fish fauna of a mixed meadow composed by the seagrasses Cymodocea nodosa and Zostera noltii in the Western Mediterranean
}

\author{
Paolo GUIDETTI *, Simona BUSSOTTI \\ Laboratorio di Zoologia e Biologia Marina, Dipartimento di Biologia, Università degli Studi di Lecce, \\ Via Provinciale Lecce-Monteroni, 73100 Lecce, Italy
}

Received 31 March 2000; revised 23 June 2000; accepted 26 June 2000

\begin{abstract}
The fish fauna of a shallow meadow composed by the seagrasses Cymodocea nodosa and Zostera noltii was studied in the Gulf of Olbia (NE Sardinia, Italy; Western Mediterranean). Visual censuses were conducted monthly from August 1995 to August 1996. Environmental variables for water temperature, salinity and seagrass shoot density were collected on each sampling occasion. A total of 23 fish species from eight families were recorded. Planktivorous species (Atherinids) numerically dominated the fish community, followed by necto-benthic fish, chiefly Labrids and Sparids. There was no discernible trend in total fish density. Species richness, diversity, evenness and density of necto-benthic species, instead, displayed a distinct seasonal pattern, higher values occurring from late spring to early autumn. All community variables, except total fish density, were positively related to water temperature and shoot density, but not to salinity. Multivariate analysis revealed variation in species composition and relative abundances of the fish community throughout the year. The most common fish species displayed different seasonal patterns of density throughout the year. Differences were also found in the relationships between the relative abundances of each species with the environmental variables (water temperature, salinity) and the seagrass shoot density. The data show that the fish fauna of the meadow of Olbia was characterised by a distinct seasonal variation of the community structure, probably influenced by the fluctuations of both environmental variables and habitat complexity. Since seasonal variations in fish density were due to the contribution of juvenile, sub-adult and adult specimens, the data presented here imply both recruitment and migration phenomena from and towards adjacent habitats in the colonisation of the bed during warmer months. The presence of juvenile fishes of a number of species emphasises the potentially important function of nursery exerted by such seagrass systems during the first phases of the life history of several fish species. (C) 2000 Ifremer/CNRS/IRD/Éditions scientifiques et médicales Elsevier SAS
\end{abstract}

fish fauna / seagrasses / seasonal variations / Mediterranean

Résumé - Ichtyofaune d'une pelouse mixte à Cymodocea nodosa et Zostera noltii en Méditerranée occidentale. La faune ichtyologique associée aux phanérogames marines méditerranéennes de petite taille (Cymodocea nodosa et Zostera noltii) à été étudiée près d'une pelouse mixte peu profonde dans le golfe d'Olbia (Sardaigne nord-orientale, Italie). Des recensements visuels ont été réalisés mensuellement d'août 1995 à août 1996. La température, la salinité de l'eau et la densité des faisceaux ont été mesurées à chaque échantillonnage. Un total de vingt trois espèces de poissons, appartenant à huit familles, ont été recensés. Les poissons planctonophages (Atherinidae) dominent toute l'année, suivis par les poissons necto-benthiques (Labridae et Sparidae). La densité totale des poissons ne présente pas de variations saisonnières. Par contre, la richesse spécifique, la diversité, l'équitabilité et la densité des espèces necto-benthiques présentent des valeurs plus élevées de la fin du printemps

\footnotetext{
* Correspondence and reprints.

E-mail address: paolo.guidetti@unile.it (P. Guidetti).
}

(c) 2000 Ifremer/CNRS/IRD/Éditions scientifiques et médicales Elsevier SAS. Tous droits réservés. 
à l'été. Toutes les variables du peuplement de poissons, exceptée la densité, sont positivement corrélées à la température de l'eau et la densité des faisceaux, et négativement à la salinité. L'analyse multivariée met en évidence un cycle annuel du peuplement ichtyologique. Les espèces des poissons les plus communes présentent différents cycles de variation de leur densité. Labrus viridis est la seule espèce dont la densité est significativement corrélée à la température, la salinité de l'eau et la densité des faisceaux. La densité des Atherinidae, des Labridae (Symphodus tinca, S. cinereus), de Milludae (Mullus surmuletus) et de Sparidae (Diplodus annularis) est significativement corrélée à la température de l'eau et la densité des faisceaux. L'abondance de Coris julis et Sarpa salpa est positivement corrélée à la température de l'eau et à la densité des faisceaux, respectivement, tandis que celle de G. bucchichii et $D$. vulgaris l'est négativement à la salinité. Les données montrent que la faune ichtyologique associée à la pelouse superficielle à $C$. nodosa et $Z$. noltii étudiée est caractérisée par une évidente variation saisonnière et que, soit les variables environnementales, soit la complexité de l'habitat, affectent la structure de la communité ichtyologique. Les variations saisonnières de la densité du peuplement de poisson sont marquées par la contribution des jeunes individus, ce qui suggère un rôle important de recrutement et la fonction de nourrisserie des prairies mixte à Cymodocea et Zostera. Les contributions des adultes et des sub-adultes traduisent plutôt des phénomènes de migration pendant les mois les plus chauds. (C) 2000 Ifremer/ CNRS/IRD/Éditions scientifiques et médicales Elsevier SAS

\section{Ichtyofaune / phanérogames marines / variations seasonnières / Mediterranée}

\section{INTRODUCTION}

Seagrass beds have long been considered as the most productive and architecturally complex systems of the coastal zones on a world-wide scale (Den Hartog, 1970). For these reasons, they are able to support diverse fish assemblages and exert a paramount role as nursery grounds for juveniles of many commercially important fish species (Pollard, 1984; Bell and Pollard, 1989).

Previous studies have focused on the relationships between abundance and diversity of fish, and the structural complexity of seagrass systems (i.e. measured as leaf biomass or shoot density) (Adams, 1976; Orth and Heck, 1980; Young, 1981; Bell and Westoby, 1986a; Fonseca et al., 1996). Seagrass beds, in fact, are classically thought to provide shelter from predators and greater abundance of food (mainly small invertebrates) for many littoral fish species. Bell and Westoby (1986b) provided evidence of a strong positive relationship between small fish abundance and seagrass density regardless of the absence/presence of predators, suggesting the possibility that fish are able to select among more or less dense seagrass beds or adjacent unvegetated areas. Unvegetated areas usually host different fish assemblages characterised by fewer fish and fewer species (Bell and Pollard, 1989; Connolly, 1994a; Gray et al., 1998; Guidetti, 2000).
In the Mediterranean Sea, several authors have studied the fish fauna associated with Posidonia oceanica (Bell and Harmelin-Vivien, 1982; Harmelin-Vivien, 1982; Harmelin-Vivien and Francour, 1992; Francour, 1994; Francour, 1997; Guidetti et al., 1998; Guidetti, 2000; Guidetti and Bussotti, 1997), the most widespread and productive seagrass endemic of the basin (Mazzella et al., 1993). Moreover, some authors have recently confirmed that shallow sheltered $P$. oceanica meadows may serve as a nursery for several fish species (Francour and Le Direac'h, 1994; Guidetti and Bussotti, 1998; Guidetti and Bussotti, 1997). In general, however, the fish faunas associated with Mediterranean marine phanerogams other than $P$. oceanica, have received little or no attention thus far (Bussotti and Guidetti, 1996, 1999). Concomitantly, C. nodosa, often mixed with $Z$. noltii, which dominates at shallow depths in Mediterranean coastal lagoons and sheltered coves (Mazzella et al., 1993; Marbà et al., 1996), is among those seagrasses that have yet to receive attention. Preliminary surveys conducted on the fish fauna associated with mixed stands of $C$. nodosa and $Z$. noltii indicated a rich fish community during the warmer season of the year. However, despite the extension of such systems and their potential importance in several areas of the Mediterranean Sea (Marbà et al., 1996; Laugier et al., 1999) information on the fish fauna associated with 
these vegetated ecosystems is still scanty (Bussotti and Guidetti, 1996, 1999).

The baseline differences in the habitat features offered by $P$. oceanica systems and those composed by $C$. nodosa and $Z$. noltii are most obviously due to differences in plant size and their seasonal dynamics (Mazzella et al., 1993; Marbà et al., 1996). Posidonia oceanica has longer leaves and display a comparatively more stable architectural complexity throughout the year, while the C. nodosa-Z. noltii complex is characterised by marked seasonal changes of the main structural variables (e.g. shoot density) (Mazzella et al., 1993; Marbà et al., 1996). The leaf canopy of $C$. nodosa and $Z$. noltii is well developed during the warmer months and decreases or completely disappears at the onset of the colder season (Den Hartog, 1970; Mazzella et al., 1993; Marbà et al., 1996).

This paper represents a contribution to the study of the annual cycle of the fish community associated with a mixed meadow composed by $C$. nodosa and $Z$. noltii in the Mediterranean Sea. Our objectives are: 1) to describe annual structure of the fish fauna associated with $C$. nodosa and $Z$. noltii; 2) to evaluate the potential relationships between the fish community variables (species, richness, fish density, diversity and evenness) and individual fish species density with the environmental variables (water temperature and salinity) and the seagrass shoot density throughout the year; and 3) to investigate the pres-

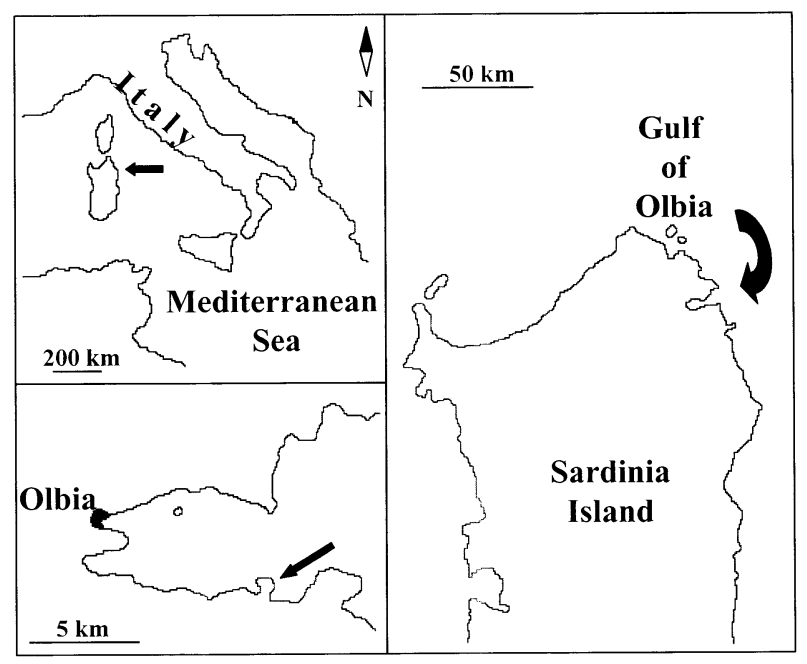

Figure 1. Location of the study area. ence of juvenile fishes in order to highlight the possible role as nursery areas of the seagrasses investigated.

\section{MATERIALS AND METHODS}

\subsection{Study area}

This study was conducted in a sheltered cove, Baia delle Saline (Gulf of Olbia, NE Sardinia, Italy: $40^{\circ} 55.5^{\prime} \mathrm{N}, 09^{\circ} 34.4^{\prime} \mathrm{E}$; figure 1). Seagrass meadows of $C$. nodosa and $Z$. noltii are well developed both in coastal lagoons connected to the sea and sheltered coves. Surrounding the study site, $C$. nodosa and $Z$. noltii form homogeneous beds and are found in shallow water (in some cases less than $0.5 \mathrm{~m}$ depth) on gentle sloped coarse sandy bottoms. At depths greater than 3-4 m over sand bottom, C. nodosa and $Z$. noltii are replaced by sparse patches of $P$. oceanica located at a distance of some tens of metres from the mixed meadow.

\subsection{Data collection and analysis}

Water temperature and salinity were measured during each visit. To evaluate seasonal changes of the meadow physiognomy, the shoot density of the seagrasses ( $C$. nodosa and $Z$. noltii pooled) was measured monthly by counting the number of shoots within frames $20 \times 20 \mathrm{~cm}$ (ten replicates during each visit). These density estimates were then converted to a square meter and averaged. Shoot density is considered as one of the best descriptors of seasonal changes in the meadow physiognomy (Mazzella et al., 1993; Marbà et al., 1996).

From August 1995 to August 1996, visual estimates of fishes were conducted monthly along eight replicated transects $\left(25 \mathrm{~m}\right.$ long and $6 \mathrm{~m}$ wide: $150 \mathrm{~m}^{2}$ of total surface) randomly placed between 0.5 and $1.5 \mathrm{~m}$ depth. Fish were counted on the basis of pre-established discrete abundance classes $(1,2-5,6-10,11-$ $30, \quad 31-50, \quad 51-100, \quad 101-200, \quad 201-500, \quad>500)$ (Harmelin-Vivien et al., 1985). Fish density (number of individuals $150 \mathrm{~m}^{-2}$ ) was calculated by taking into account the mid point of each abundance class. The size structure of the fish species recorded were ob- 


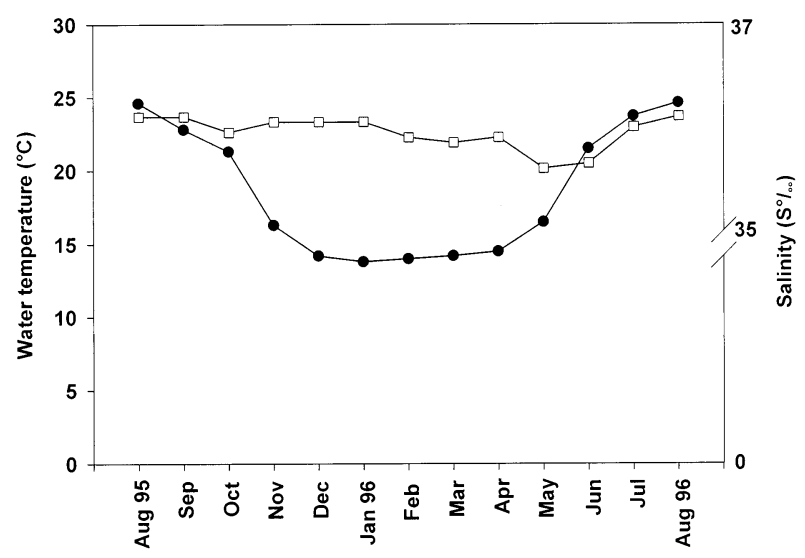

Figure 2. Annual trend of the surface water temperature (filled circles) and salinity (empty squares) at the meadow studied from August 1995 to August 1996.

tained considering three categories, namely juvenile, sub-adult and adult specimens, on the basis of the fish size and livery (Bini, 1968; Harmelin-Vivien et al., 1985). Species richness (S), Shannon-Wiener diversity index $\left(\mathrm{H}^{\prime}\right)$, evenness $(\mathrm{J})$ and percentage of frequency of occurrence of each species were calculated. The density of most common species, arbitrarily considered as the species showing a frequency of occurrence higher than $15 \%$ over the year, was also calculated.

Analysis of variance (one way ANOVA) was used to test differences in the seagrass shoot density throughout the year. The same statistical procedure was employed to test the null hypothesis that there were no differences in the fish density across the year. Thus, 'month' was considered as a fixed factor in the analysis. Before each analysis, all data susceptible to be processed by parametric ANOVAs were tested by Kolmogorov-Smirnov (for normality) and Cochran's tests (for homogeneity of variances) and, whenever necessary, they were appropriately transformed and newly tested (Underwood, 1997). Multiple comparisons a posteriori were made by SNK test. As for the estimates of relative mean adundances of most common fish species, however, since data were collected according an arbitrary scale of abundance, the assumption of normality is violated. Thus, the fact that some of them came out normal must be considered accidental. The overall data set, therefore, was preventively $\log$-transformed $[\log (x+1)]$ to reduce the relationship between means and variances.
Planktivorous fish species were excluded from some analyses. Previous studies have indicated that benthic habitats are less important for these species (Connolly, 1994b), which, in addition, may occlude variations in abundance of the remaining species (Ferrell and Bell, 1991).

Fish density data were entered into a species/sampling matrix and used for a AFC analysis (factorial analysis of correspondences) (Legendre and Legendre, 1983) in which abundance data were log-transformed $[\log (x+1)]$.

Correlation analyses were used to assess the relationship between environmental variables (water temperature and salinity) and the seagrass shoot density with fish community variables (species richness, diversity, fish density with and without planktivorous fish) and the density of most common fish species.

\section{RESULTS}

\subsection{Environmental variables, seagrass shoot density and general features of the fish community}

Water temperature at the site varied from $13.8^{\circ} \mathrm{C}$ in January to $24.6{ }^{\circ} \mathrm{C}$ in August (figure 2). Salinity was lower in winter-spring and slightly higher in summer-autumn, from 35.60 (May) to 36.10\% (August-September) (figure 2).

The annual fluctuation of the shoot density of $C$. nodosa and $Z$. noltii is shown in figure 3. Significant differences were observed through the year between August 1995 and August 1996 (ANOVA, $P<0.001$ ). Higher density was recorded in summer, with the maximum in August 1995 (mean \pm SE: $1776.0 \pm$ 26.2), and lower values in late autumn and winter, with the minimum in December 1995 (mean $\pm \mathrm{SE}$ : $954.5 \pm 7.0)$ (SNK test, $P<0.05)$.

A total of 23 fish species from eight families were recorded during the study period (table I). Atherinids were the most abundant taxon each month during sampling and had the highest frequency of occurrence followed by some labrid species, such as Symphodus cinereus, S. tinca and Labrus viridis, and Sparids, like Sparus aurata, Diplodus vulgaris, D. annularis and Sarpa salpa. The bulk of the remaining species were less abundant or occasional (table I). 


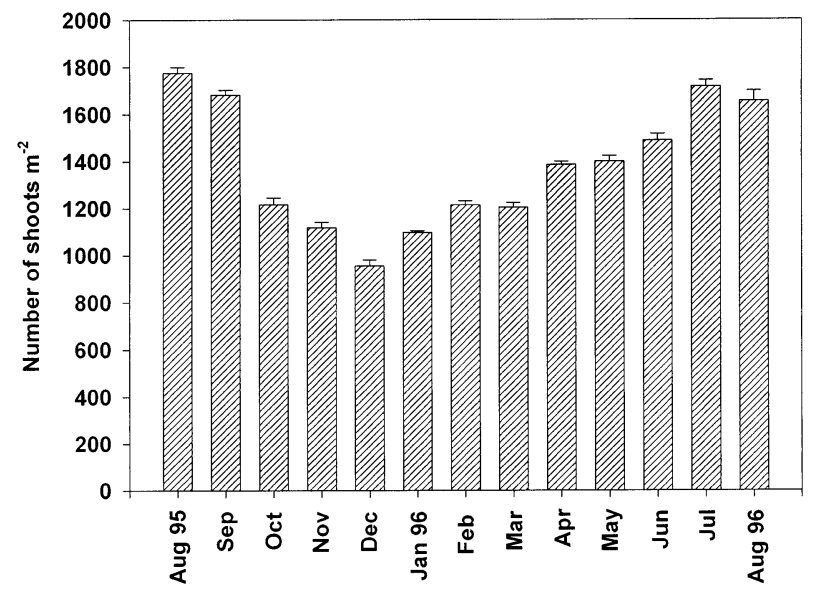

Figure 3. Shoot density fluctuation from August 1995 to August 1996. Means \pm SE.

The annual trend of the species richness is shown in figure $4 a$. Higher values were recorded in summer (with the maximum in August 1996), while the lower ones occurred in late winter and yearly spring (January to April 1996).
The total fish density did not show any distinct annual trend (figure $4 b$ ), although significant differences month by month were detected (ANOVA, $P<$ 0.001 ). The highest value was observed in January 1996 (SNK, $P<0.05$ ), mainly attributable to the high density of Atherinids. On the contrary, the fish density of necto-benthic species showed a distinct trend with an evident decrease from August 1995 to April 1996 (figure 4c), followed in May 1996 by a dramatic increase. This peak was chiefly due to the presence of juvenile Atherinids and D. vulgaris. The following increase from June to August 1996, as well as the high values of the August 1995, were chiefly due to the presence of juvenile, subadult and adult Symphodus spp., D. annularis and Sarpa salpa.

Diversity and evenness of the fish community showed similar trends with high values in August-September 1995 followed by a decrease from October to April and an increase from May to August 1996 (figure 5).

Species richness, necto-benthic fish density, diversity and evenness were significantly and positively related to both water temperature and shoot density, but not

Table I. List of fish species recorded at the mixed meadow of C. nodosa and Z. noltii in the Gulf of Olbia between August 1995 and August 1996.

\begin{tabular}{|c|c|c|c|c|c|c|}
\hline Family & Species & $\mathrm{F}$ & $\mathrm{D}$ & $\mathrm{j}$ & $\mathrm{s}$ & $\mathrm{a}$ \\
\hline Atherinidae & Undetermined & 98.1 & $112.8 \pm 15.6$ & 18 & 82 & - \\
\hline Belonidae & Belone belone & 1.9 & $0.02 \pm 0.02$ & - & 100 & - \\
\hline \multirow{2}{*}{ Gobiidae } & Gobius bucchichii & 25.0 & $0.3 \pm 0.2$ & - & 100 & - \\
\hline & Gobius niger & 13.5 & $0.2 \pm 0.1$ & - & 100 & - \\
\hline \multirow[t]{7}{*}{ Labridae } & Coris julis & 36.5 & $0.5 \pm 0.1$ & 23 & 67 & - \\
\hline & Labrus viridis & 34.6 & $1.4 \pm 0.2$ & 69 & 31 & - \\
\hline & Symphodus cinereus & 85.6 & $4.9 \pm 2.4$ & 37 & 51 & 12 \\
\hline & Symphodus ocellatus & 13.5 & $0.3 \pm 0.2$ & 100 & - & - \\
\hline & Symphodus tinca & 57.7 & $3.6 \pm 1.2$ & 41 & 57 & 2 \\
\hline & Symphodus roissali & 3.8 & $0.06 \pm 0.06$ & 40 & 40 & 20 \\
\hline & Symphodus rostratus & 1.9 & $0.02 \pm 0.02$ & - & 100 & - \\
\hline Mugilidae & Undetermined & 11.5 & $1.3 \pm 0.1$ & - & 100 & - \\
\hline Mullidae & Mullus surmuletus* & 21.1 & $0.4 \pm 0.2$ & 62 & 31 & 7 \\
\hline Serranidae & Serranus scriba & 3.8 & $0.05 \pm 0.03$ & - & 100 & - \\
\hline \multirow[t]{9}{*}{ Sparidae } & Diplodus annularis* & 32.7 & $3.0 \pm 0.8$ & 90 & 4 & 6 \\
\hline & Diplodus puntazzo* & 9.6 & $0.2 \pm 0.1$ & - & 100 & - \\
\hline & Diplodus sargus* & 3.8 & $0.06 \pm 0.04$ & 20 & 80 & - \\
\hline & Diplodus vulgaris* & 34.6 & $3.0 \pm 2.2$ & 32 & 65 & 3 \\
\hline & Lythognathus mormyrus* & 1.9 & $0.2 \pm 0.2$ & 100 & - & - \\
\hline & Oblada melanura* & 1.9 & $0.02 \pm 0.02$ & 100 & - & - \\
\hline & Pagrus pagrus* & 3.8 & $0.04 \pm 0.04$ & 100 & - & - \\
\hline & Sarpa salpa & 32.7 & $8.0 \pm 3.4$ & 36 & 64 & - \\
\hline & Sparus aurata* & 38.5 & $0.9 \pm 0.3$ & 100 & - & - \\
\hline
\end{tabular}

* Fish species of economical or recreational value. Size structure (\%). F, frequency of occurrence (\%); D, no. individuals $150 \mathrm{~m}^{-2}$; mean $\pm \mathrm{SE} ; \mathrm{j}$, juvenile; s, sub-adult; a, adult. 


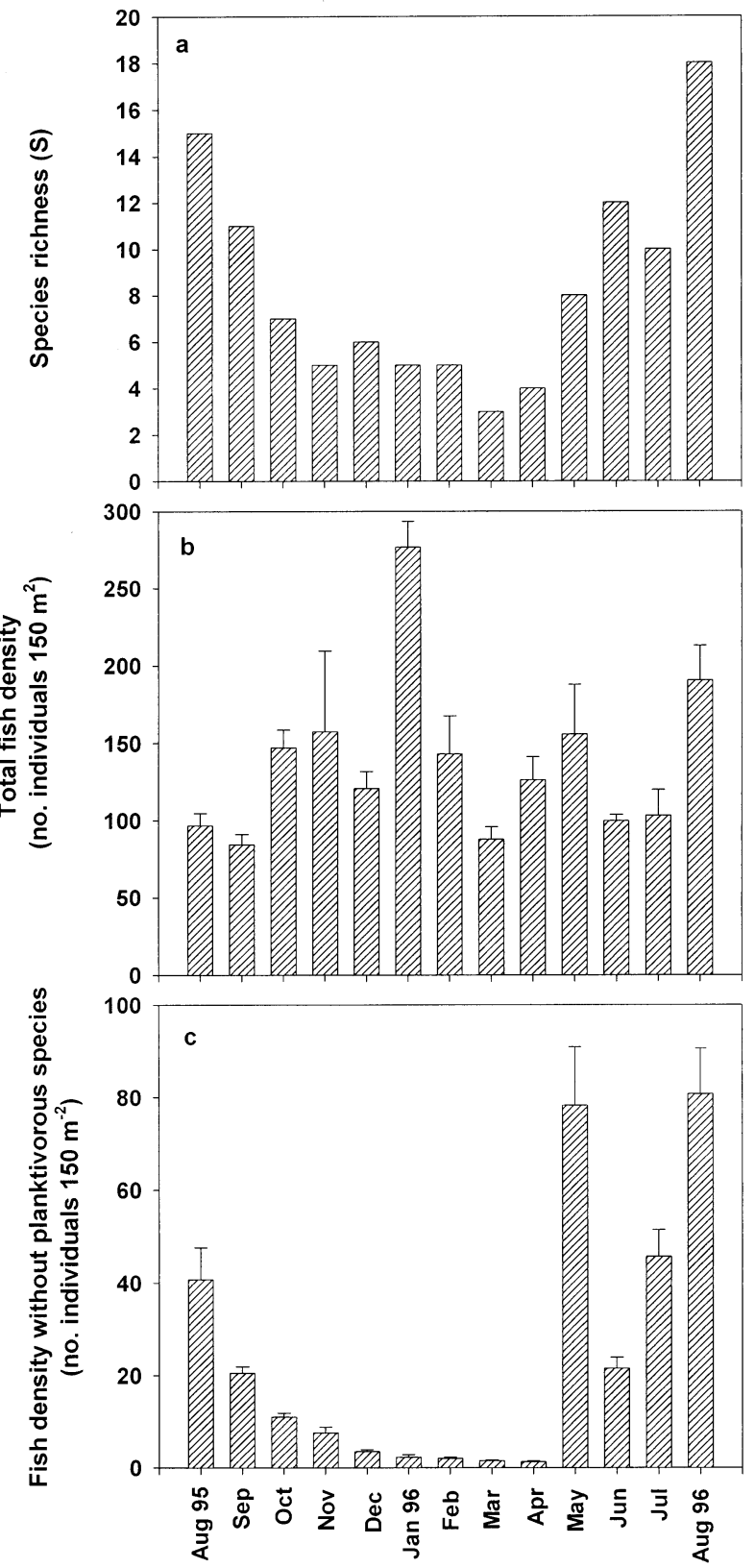

Figure 4. (a) Annual trend of the species richness. (b) Annual trend of the mean fish density (no. individuals $150 \mathrm{~m}^{-2}$ ), means \pm SE. (c) Annual trend of the mean necto-benthic fish density (no. individuals $150 \mathrm{~m}^{-2}$ ), means $\pm \mathrm{SE}$.

to salinity (table II). The total fish density, instead, did not show any significant relationship (table II).

The ordination model obtained by AFC, in which the first two axes accounted for $43.2 \%$ and $14.7 \%$, re- spectively, of the total variance, showed a clear cycling in the disposal of different sampling points (figure 6). Observation points related to samplings conducted from January to April are grouped together and positioned in the positive space of the first axis (CA1), highlighting a relative stability of the fish community structure in winter and yearly spring. Differently, the observation points from May to September are well separated from the others, plotted in the negative pole of the first axis and well scattered along the second axis (CA2).

\subsection{Annual patterns in density of most common fish species}

A number of 11 fish species showed a frequency of occurrence higher than $15 \%$ (table I). All these species showed significant differences in the mean density over the year (ANOVA, $P<0.01$ ), but different seasonal patterns (figure 7). Coris julis (figure 7a) did not display a distinct annual trend and it was never recorded from January to April. The density of $S$. tinca (figure $7 b$ ), on the contrary, appeared to clearly fluctuate in relation to season, decreasing from summer to winter and increasing from spring to the following summer. Symphodus cinereus (figure 7c) was censused during the entire year, but its density was higher during the warmer season (summer and yearly autumn) with a peak recorded in August 1996. Labrus viridis, Mullus surmuletus, Diplodus annularis,

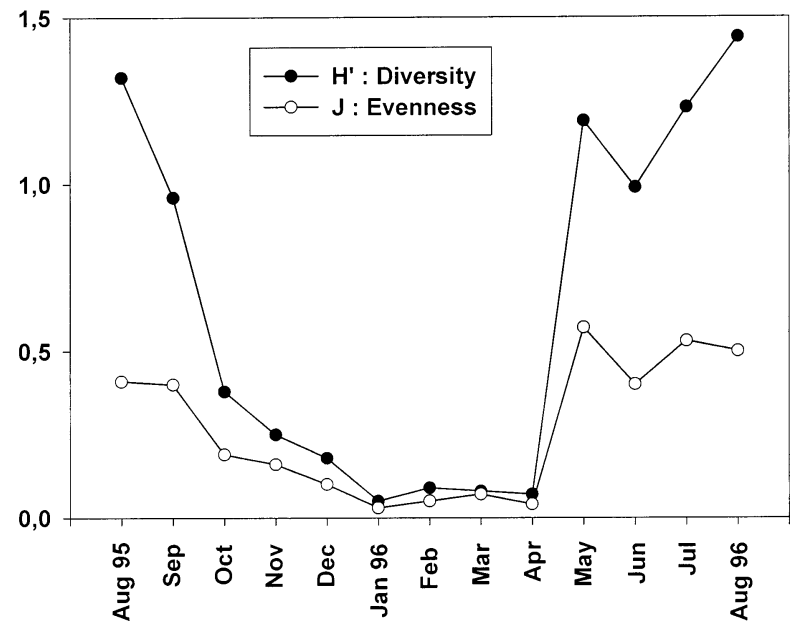

Figure 5. Annual pattern of diversity (H') and evenness (J). 
Table II. Correlation coefficients $(r)$ and probability levels $(P)$ computed between shoot density and environmental variables with community parameters and density of most common fish species. ${ }^{\mathrm{a}}$

\begin{tabular}{|c|c|c|c|c|c|c|}
\hline \multirow[t]{2}{*}{ Parameter/species } & \multicolumn{2}{|c|}{ Temperature } & \multicolumn{2}{|l|}{ Salinity } & \multicolumn{2}{|c|}{ Shoot density } \\
\hline & $r$ & $P$ & $r$ & $P$ & $r$ & $P$ \\
\hline Species richness & 0.88 & $<0.01$ & 0.22 & n.s. & 0.76 & $<0.01$ \\
\hline Total fish density & -0.30 & n.s. & 0.14 & n.s. & 0.37 & n.s. \\
\hline Necto-benthic fish density & 0.59 & $<0.05$ & 0.12 & n.s. & 0.63 & $<0.05$ \\
\hline Diversity (H') & 0.85 & $<0.01$ & 0.10 & n.s. & 0.83 & $<0.01$ \\
\hline Evenness $(\mathrm{J})$ & 0.77 & $<0.01$ & 0.12 & n.s. & 0.76 & $<0.01$ \\
\hline Atherinidae (undetermined) & -0.56 & $<0.05$ & 0.20 & n.s. & -0.53 & $<0.01$ \\
\hline Gobius bucchichii & -0.17 & n.s. & -0.84 & $<0.01$ & 0.04 & n.s. \\
\hline Coris julis & 0.62 & $<0.05$ & 0.30 & n.s. & 0.24 & n.s. \\
\hline Labrus viridis & 0.76 & $<0.01$ & 0.62 & $<0.05$ & 0.56 & $<0.01$ \\
\hline Symphodus cinereus & 0.56 & $<0.05$ & 0.30 & n.s. & 0.43 & $<0.01$ \\
\hline Symphodus tinca & 0.88 & $<0.01$ & 0.47 & n.s. & 0.73 & $<0.01$ \\
\hline Mullus surmuletus & 0.70 & $<0.01$ & 0.45 & n.s. & 0.61 & $<0.01$ \\
\hline Sarpa salpa & 0.36 & n.s. & -0.45 & n.s. & 0.38 & $<0.01$ \\
\hline Diplodus annularis & 0.61 & $<0.05$ & 0.40 & n.s. & 0.47 & $<0.01$ \\
\hline Diplodus vulgaris & 0.06 & n.s. & -0.67 & $<0.01$ & 0.10 & n.s. \\
\hline Sparus aurata & 0.46 & n.s. & 0.48 & n.s. & 0.10 & n.s. \\
\hline
\end{tabular}

${ }^{\text {a }}$ n.s., not significant.

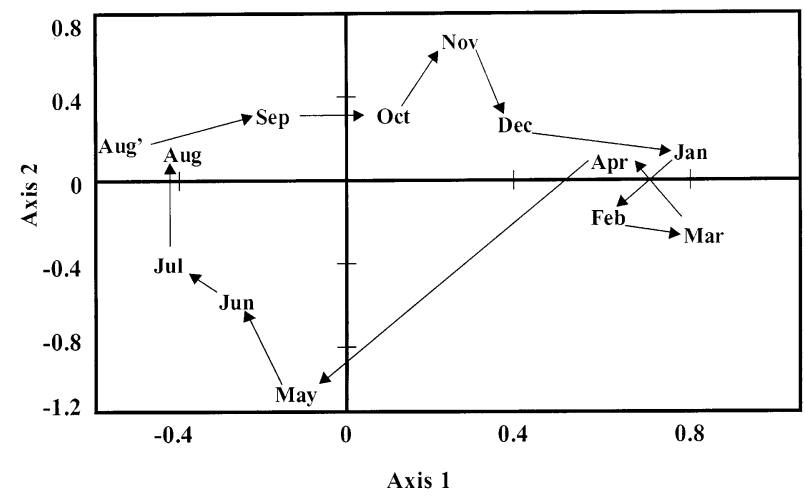

Figure 6. Ordination model obtained by AFC.

D. vulgaris and Sparus auratus (figure $7 d, g, h, i, k$ ) were recorded only in the summer-autumn period, while Sarpa salpa (figure 7j) was censused from midspring to the end of summer. Gobius bucchichii (figure $7 f$ ) was observed from February to July with a high value in May. Atherinids (figure 7e) were recorded all around the year and showed higher densities during winter, differently from the bulk of the remaining species.
In table II are shown the results of the correlation analyses relating water temperature, salinity and seagrass shoot density with the density of most common species. The abundance of $L$. viridis only was significantly related to all the three variables, while other species, namely $S$. cinereus, $S$. tinca, $D$. annularis and $M$. surmuletus, were positively related to water temperature and seagrass shoot density. Atherinids were negatively related with the water temperature and the seagrass shoot density. Coris julis and Sarpa salpa showed a significant positive relationship with water temperature and shoot density, respectively, while Diplodus vulgaris and Gobius bucchichii were negatively related with salinity.

\section{DISCUSSION AND CONCLUSIONS}

Most previous research on fish communities associated with Mediterranean seagrasses concerns $P$. oceanica meadows, while exhaustive studies on fish from seagrass beds formed by other marine phanerogams are lacking. The comparison between the fish community associated with $C$. nodosa and $Z$. noltii in the Gulf of Olbia and those found in $P$. oceanica showed some general characteristics. Simi- 

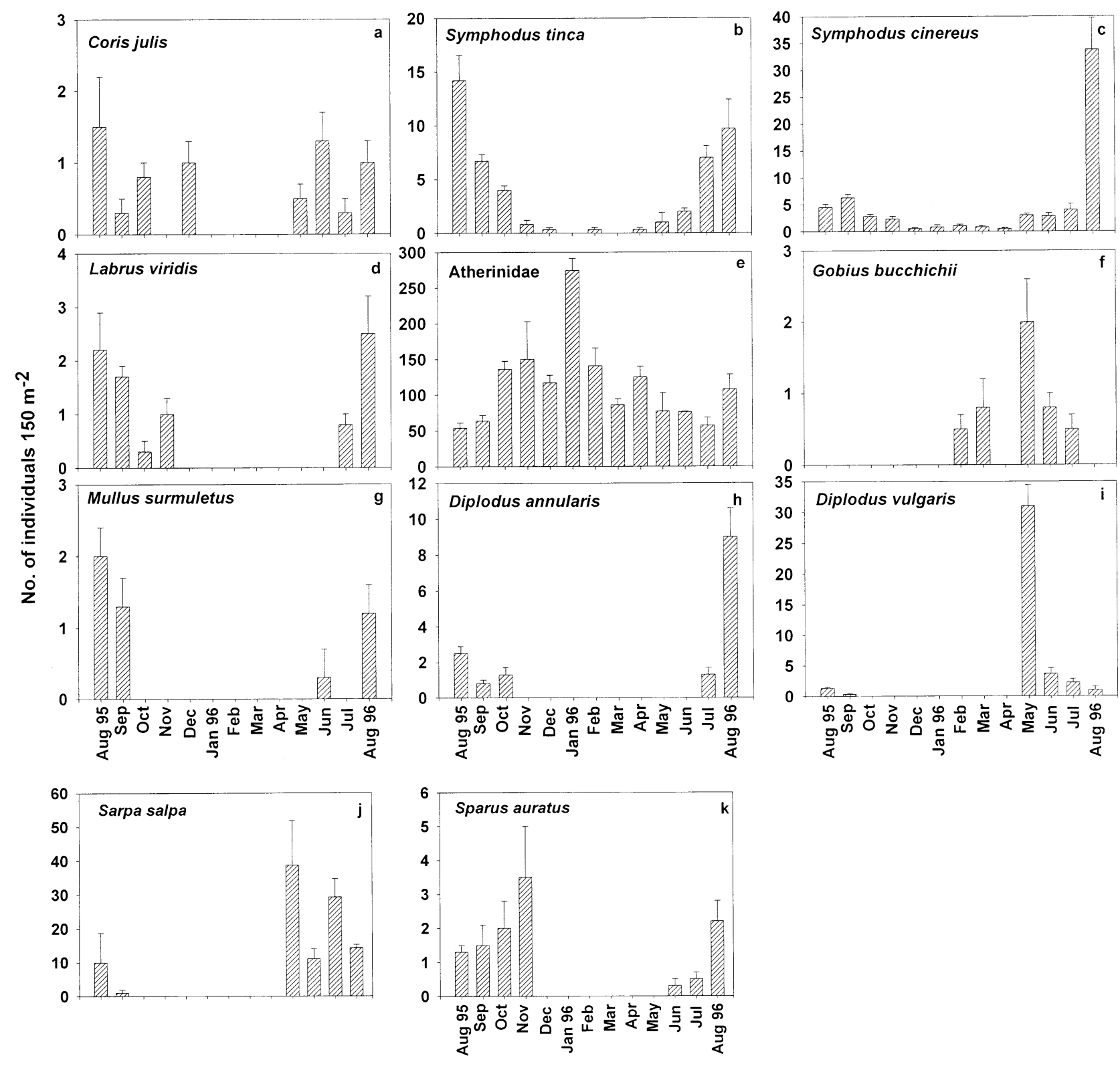

Figure 7. Annual pattern of the mean density of most common fish species. Means \pm SE.

larities include the dominance of planktivorous species and the presence of some specious families like Labrids. Although the relative abundance of several fish species may differ in the two ecosystems, the above common characteristics could be considered as basic features of fish communities of Mediterranean seagrass ecosystems (Harmelin-Vivien and Francour, 1992; Francour, 1997; Guidetti et al., 1998; Guidetti,
2000). Nevertheless, such a similarity occurs only in summer, when the fish community associated with the C. nodosa-Z. noltii complex is well structured. This overall community similarity seems to be consistent with the typical physiology and dynamics of the two systems considered. Posidonia oceanica, in fact, is a larger plant whose growth and seasonal dynamics are relatively independent of season due to its capa- 
bility to store resources. Cymodocea nodosa and Z. noltii, instead, are characterised by smaller size and strongly respond to seasonal forcing (Marbà et al., 1996). Thus, P. oceanica maintains a high and comparatively stable structural architecture through the year, while the other two seagrasses show an evident seasonality mainly of the leaf canopy, as revealed by the annual fluctuation of the shoot density presented here. The marked annual dynamics of the aboveground compartment of $C$. nodosa and $Z$. noltii (which account for the habitat complexity) could be one of the factors affecting the seasonal variations of the associated fish fauna. This fundamentally distinguishes the necto-benthic fish community associated with $P$. oceanica and with the other two seagrasses (Bussotti and Guidetti, 1999). Therefore, the higher species richness and diversity, and the higher density of several necto-benthic fish during summer to early autumn observed in the Gulf of Olbia could be partially attributed to the availability of a more structurally complex habitat, as witnessed by the results of correlation analyses between seagrass shoot density with community variables and abundance of several individual fish species. This hypothesis is consistent with the current literature and with the conclusions drawn by several authors working in other areas, who stated that denser beds generally host richer and more diverse fish assemblages than sparser meadows or unvegetated habitats, although in some cases responses may be different depending on component species of the assemblage (Adams, 1976; Orth and Heck, 1980; Bell and Westoby, 1986b; Bell and Pollard, 1989; Williams et al., 1990; Humphries et al., 1992; Gray et al., 1998; Guidetti, 2000). The positive correlations between the structural complexity of seagrass beds and abundance and diversity of fish are commonly explained by the variation in the predation rate on fish (Stoner, 1983; Orth et al., 1984; Bell and Pollard, 1989), higher food availability (Burchmore et al., 1984; Connolly, 1994c and references therein) and habitat selection by adult and juvenile fish (Bell and Westoby, 1986b; Williams et al., 1990; Connolly, 1994c). Thus, some authors suggested that the supply of greater numbers of juveniles, through discrimination by larvae at settlement, could also cause dense beds to support more individuals then sparse beds (Bell et al., 1987; Worthington et al., 1992).

In our investigation we observed both the seasonal migration of sub-adult and adult fish from other habitats and the presence of juveniles of several species. According to the results of this study, Sogard (1989) observed that colonists of artificial seagrass units include both settlers and adult fish in contrast with Bell et al. (1988 and references therein), who found that colonists of artificial seagrass are primarily planktonic settlers. Our observations regarding migration from seagrasses towards other habitats in winter and the subsequent re-colonisation in summer, when the habitat complexity increases, contrast with the Bell and Westoby's hypothesis (Bell and Westoby, 1986c) that fishes tend to remain in the habitat in which they initially settle rather than risk movement across less sheltering substrata.

Among the species recorded in the meadow of Olbia, Atherinids were the only taxon showing a negative seasonal association with shoot density. This was in part expected since Atherinids are planktivorous fish and consequently they are not trophically dependent on the seagrass canopy. The higher abundance of adults and sub-adults observed during the colder season could be attributed to the life cycle of the species. Higher winter densities of adults (with maximum in January) in shallow and sheltered littoral habitats could be due to spawning. This hypothesis is supported by the occurrence of juveniles some months later (spring).

In our study a number of individual species and all the community variables but the total fish density were related to water temperature, while significantly relationships with salinity were restricted to few species. Although contrasting results are reported in literature (Adams, 1976; Young, 1981; Humphries et al., 1992), water temperature is usually considered as one of the most important environmental factor influencing fish distribution. Warmer seasons, in fact, are generally considered as the periods of maximum necto-benthic fish abundance and diversity in shallow seagrass habitats (Adams, 1976; Young, 1981) and this is consistent with our results from the Gulf of Olbia.

With regard to the water salinity, this environmental variable is commonly considered as influencing fish community structure and distribution only in shallow estuarine seagrass habitats along salinity gradients (Ter Morshuizen and Whitfield, 1994 and references therein). Ter Morshuizen and Whitfield (1994), however, found no relationships between fish density and 
salinity in south African Zostera capensis systems as well as Humphries et al. (1992) in southern Australia on Ruppia megacarpa beds. Other evidence from some north American estuaries, instead, suggests that the distribution of fish assemblages is strongly influenced by variations in salinity due to variations in fresh water inflows (Bottom and Jones, 1992). It has to be noted that a high number of the species sampled was exclusively or mainly represented by smallsized specimens (table I). This was the case of Symphodus ocellatus, Labrus viridis, Mullus surmuletus and several Sparids, which include some species of economical interest. These results suggest a potentially important function exerted by seagrass systems composed by $C$. nodosa and $Z$. noltii for juveniles of several littoral species in the Mediterranean Sea, as also recently observed for shallow sheltered P. oceanica beds (Francour and Le Direac'h, 1994; Guidetti et al., 1998; Guidetti and Bussotti, 1997). The importance of seagrasses as habitat for juvenile and subadult fishes, stages during which they are more susceptible to predation, is well known for other areas (Pollard, 1984; Bell and Pollard, 1989; Connolly, 1994a; Fairweather, 1991). Middleton et al. (1984), in particular, observed that juvenile fish use Zostera and Posidonia meadows in New South Wales (Australia) sequentially and attributed the migration from one to the other system to variations in the structural complexity of the canopies created by the two seagrasses. Moreover, it is well documented that several fish species both in the Mediterranean Sea (Garcia-Rubies and Macpherson, 1995) and outside (Bennett, 1989; Ruiz et al., 1993) use very shallow habitats (often less than two meters deep) for settlement, where the risk of predation is considered to be reduced (Ruiz et al., 1993). However, on the basis of our data, we cannot assess if the presence of juvenile fish is attributable to the presence of seagrasses or the shallow depth or, as more probable, to the complementary effect of both factors.

As far as the technique we used is concerned, Francour (1997) affirmed that the transect technique, together with circular points, is one of the more efficient for detecting small fishes associated with seagrasses than other visual methods. However, we think that narrower transects than those used here should be considered in studies focused on juvenile fishes, since small fish of many species could be underestimated by conducting counts along wide transects. A similar conclusion was drawn by Francour and Le Direac'h (1994), who conducted visual censuses on transects $20 \mathrm{~m}$ long and $1 \mathrm{~m}$ wide in the framework of a study focused on the assessment of the role of nursery of shallow $P$. oceanica beds. For both small and large fish, in any case, it has to be stressed that the reliability of each visual technique is related to the species considered, this depending on the behaviour, livery and size typical of each fish (Francour, 1997). With regard to the possible influence of the habitat complexity on the efficiency of the visual techniques, it can be generally supposed that more structured is the habitat, less probable is the detection of a fish. Then, we can suppose a higher bias during summer, when the shoot density reaches the maximum, mainly in the case of cryptic species.

From this study the following conclusions can be drawn:

1. The fish fauna associated with the shallow mixed meadow of $C$. nodosa and $Z$. noltii is characterised by high variations through the year with higher species richness and necto-benthic fish densities during the warmer season.

2. Several community variables and the density of a number of individual fish species are associated, in most cases positively, with seagrass shoot density and water temperature.

3. Mediterranean seagrass ecosystems constituted by other phanerogams than $P$. oceanica may host juvenile fish during the first phases of their life span.

Although further data are absolutely needed from a higher number of meadows and geographic areas in order to account for possible variations on larger spatial scales, such data suggest a potential important role of seagrass systems composed by $C$. nodosa and $Z$. noltii in the Mediterranean regions where coastal lagoons or sheltered coves are present. Nevertheless, experimental manipulations 'in situ' are necessary to account for the contribute to the total variance exclusively induced by leaf canopy (presence, absence or different shoot densities), preventing any possible effect of other superimposed factors. This study, therefore, must be conceived as the observational stage of the investigation (Underwood, 1997) on the fish fauna associated with such a Mediterranean ecosystem, since on the basis of the results presented here 
further hypotheses can be formulated and tested by appropriate experimental designs.

\section{Acknowledgements}

The authors wish to thank Prof. S. Bortone (Environmental Sciences Institute, Florida, USA) for the critical reading of the manuscript, his useful suggestions and the revision of the English text.

\section{REFERENCES}

Adams, S.M., 1976. The ecology of eelgrass, Zostera marina (L.), fish communities. I. Structural analysis. J. Exp. Mar. Biol. Ecol. 22, 269-291.

Bell, J.D., Harmelin-Vivien, M.L., 1982. Fish fauna of French Mediterranean Posidonia oceanica seagrass meadows: 1. Community structure. Tethys 10, 337-347.

Bell, J.D., Westoby, M., 1986a. Importance of local changes in leaf eight and density to fish and decapods associated with seagrasses. J. Exp. Mar. Biol. Ecol. 104, 249-274.

Bell, J.D., Westoby, M., 1986b. Abundance of macrofauna in dense seagrass is due to habitat preference, not predation. Oecologia 68, 205-209.

Bell, J.D., Westoby, M., 1986c. Variations in seagrass eight and density over a wide spatial scale: effects on fish and decapods. J. Exp. Mar. Biol. Ecol. 104, 275-295.

Bell, J.D., Westoby, M., Steffe, A.S., 1987. Fish larvae settling in seagrass: do they discriminate between beds of different leaf density? J. Exp. Mar. Biol. Ecol. 111, 133-144.

Bell, J.D., Steffe, A.S., Westoby, M., 1988. Location of seagrass beds in estuaries: effects on associated fish and decapods. J. Exp. Mar. Biol. Ecol. 122, 127-146.

Bell, J.D., Pollard, D.A., 1989. Ecology of fish assemblages and fisheries associated with seagrasses. In: Larkum, A.W.D., McComb, A.J., Shepherd, S.A. (Eds.), Biology of Seagrasses. Elsevier, Amsterdam, pp. 536-564.

Bennett, B.A., 1989. Fish community of a moderately exposed beach on the south-western cape coast of South Africa and an assessment of this habitat as a nursery for juvenile fish. Estuar. Coast. Shelf Sci. 28, 293-305.

Bini, G., 1968. Atlante dei Pesci delle Coste Italiane. Osteitti. Mondo Sommerso Editrice.

Bottom, D.L., Jones, K.K., 1992. Species composition, distribution, and invertebrate prey of fish assemblages in the Columbia River estuary. Prog. Oceanogr. 25, 243-270.

Burchmore, J.J., Pollard, D.A., Bell, J.D., 1984. Community structure and trophic relationships of the fish fauna of an estuarine Posidonia australis seagrass habitat in Port Hacking, New South Wales. Aquat. Bot. 18, 71-87.
Bussotti, S., Guidetti, P., 1996. Preliminary data on fish fauna associated with a Cymodocea nodosa (Ucria) Aschers. and Zostera noltii Hornem. mixed meadow in the Gulf of Olbia (Sardinia-Tyrrhenian Sea). Mésogée 55, 9-14.

Bussotti, S., Guidetti, P. 1999. Fish communities associated with different seagrass systems in the Mediterranean Sea. In: Vacchi, M. (Ed.), Proceedings of the International Workshop: Fish Visual Census in Marine Protected Areas. Ustica 26-28 June 1997, Il Naturalista Siciliano 23, pp. 245-259

Connolly, R.M., 1994a. A comparison of fish assemblages from seagrass and unvegetated areas of a Southern Australian estuary. Aust. J. Mar. Freshwater Res. 45, 1033-1044.

Connolly, R.M., 1994b. Removal of seagrass canopy: effects on small fish and their prey. J. Exp. Mar. Biol. Ecol. 184, 99-110.

Connolly, R.M., 1994c. The role of seagrass as preferred habitat for juvenile Sillaginodes punctata (Cuv. \& Val.) (Sillaginidae, Pisces): habitat selection or feeding? J. Exp. Mar. Biol. Ecol. 180, 39-47.

Den Hartog, C., 1970. The seagrasses of the world. Elsevier, Amsterdam, London.

Fairweather, P.G., 1991. Implication of 'supply-side' ecology for environmental assessment and management. Trends Ecol. Evol. $6,60-63$.

Ferrell, J.D., Bell, J.D., 1991. Differences among assemblages of fish associated with Zostera capricorni and bare sand over a large spatial scale. Mar. Ecol. Prog. Ser. 72, 15-24.

Fonseca, M.S., Meyer, D.L., Hall, M.O., 1996. Development of planted seagrass beds in Tampa Bay, Florida, USA. II. Faunal components. Mar. Ecol. Prog. Ser. 132, 141-156.

Francour, P., 1994. Pluriannual analysis of the reserve effect on ichthyofauna in the Scandola Marine Reserve (Corsica, Northwestern Mediterranean). Oceanol. Acta 17, 309-317.

Francour, P., 1997. Fish assemblage of Posidonia oceanica beds at Port-Cros (France, NW Mediterranean): assessment of composition and long-term fluctuations by visual census. P.S.Z.N. I: Mar. Ecol. 18, 157-173.

Francour, P., Le Direac'h, L., 1994. Recrutement de l'ichtyofaune dans l'herbier superficiel à Posidonia oceanica de la réserve naturelle de Scandola (Corse, Méditerranée nord-occidentale): données préliminaires. Travaux Scientifiques du Parc National et Régional Réserve Corse 46, 71-91.

Garcia-Rubies, A., Macpherson, E., 1995. Substrate use and temporal pattern of recruitment in juvenile fishes of the Mediterranean littoral. Mar. Biol. 124, 35-42.

Gray, C.A., Chick, R.C., McElligot, D.J., 1998. Diel changes in assemblages of fishes associated with shallow seagrass and bare sand. Estuar. Coast. Shelf Sci. 46, 849-859.

Guidetti, P., Bussotti, S., 1998. Juveniles of littoral fish species in shallow seagrass beds: preliminary quali-quantitative data. Biol. Mar. Medit. 5, 347-350.

Guidetti, P., Bussotti, S., Conti, M., 1998. Fish fauna of the Genoa-Quinto Posidonia oceanica bed (Ligurian Sea, NorthWestern Mediterranean). Rapp. Comm. Int. Mer Médit. 35, 546-547. 
Guidetti, P., Bussotti, S., 1997. Recruitment of Diplodus annularis and Spondyliosoma cantharus (Sparidae) in shallow seagrass beds along the Italian coasts (Mediterranean Sea), Marine Life 7, 47-52.

Guidetti, P., 2000. Differences among fish assemblages associated with nearshore Posidonia oceanica beds, rocky-algal reefs and unvegetated sand habitats in the Adriatic Sea. Estuar. Coast. Shelf Sci. 50, 515-529.

Harmelin-Vivien, M.L., 1982. Ichtyofaune des herbiers de posidonies du parc national de Port-Cros: 1. Composition et variation spatio-temporelles. Trav. Sci. Parc nation. Port-Cros 8, 69-92.

Harmelin-Vivien, M.L., Harmelin, J.G., Chauvet, C., Duval, C., Galzin, R., Lejeune, P., Barnabe, G., Chevalier, R., Duclerc, J., Lasserre, G., 1985. Evaluation des peuplements et populations de poissons. Méthodes et problèmes. Rev. Ecol. (Terre Vie) 40, 467-539.

Harmelin-Vivien, M.L., Francour, P., 1992. Trawling or visual censuses? Methodological bias in the assessment of fish populations in seagrass beds. P.S.Z.N.I: Mar. Ecol. 13, $41-51$.

Humphries, P., Potter, I.C., Loneragan, N.R., 1992. The fish community in the shallows of a temperate Australian estuary: relationships with the aquatic macrophyte Ruppia megacarpa and environmental variables. Estuar. Coast. Shelf Sci. 34, 325-346.

Laugier, T., Rigollet, V., de Casabianca, M.L., 1999. Seasonal dynamics in mixed eelgrass beds, Zostera marina L. and $Z$. noltii Hornem., in a Mediterranean coastal lagoon (Thau lagoon, France). Aquat. Bot. 63, 51-69.

Legendre, L., Legendre, P., 1983. Numerical ecology. Development in environmental modelling. 3. Elsevier, Amsterdam.

Marbà, N., Cebrian, J., Enriquez, S., Duarte, C.M., 1996. Growth patterns of Western Mediterranean seagrasses: species-specific responses to seasonal forcing. Mar. Ecol. Prog. Ser. 133, 203215.

Mazzella, L., Scipione, M.B., Gambi, M.C., Buia, M.C., Lorenti, M., Zupo, V., Cancemi, G., 1993. The Mediterranean seagrasses Posidonia oceanica and Cymodocea nodosa. A comparative overview. In: Ozhan, E. (Ed.), The First International Conference on Mediterranean Coastal Environment. MEDCOAST 93, Antalya, Turkey, pp. 103-116.
Middleton, M.J., Bell, J.D., Burchmore, J.J., Pollard, D.A., Pease, B.C., 1984. Structural differences in the fish communities of Zostera capricorni and Posidonia australis seagrass meadows in Botany Bay, New South Wales. Aquat. Bot. 18, 89-109.

Orth, R.J., Heck Jr, K.L., 1980. Structural components of eelgrass (Zostera marina) meadows in the lower Chesapeake Bay Fishes. Estuaries 3, 278-288.

Orth, R.J., Heck, K.L., Van Montfrans, J., 1984. Faunal communities in seagrass beds: a review of the influence of plant structure and prey characteristic on predator-prey relationships. Estuaries 7, 339-350.

Pollard, D.A., 1984. A review of ecological studies on seagrass-fish communities with particular reference to recent studies in Australia. Aquat. Bot. 18, 3-42.

Ruiz, G.M., Hines, A.H., Posey, M.H., 1993. Shallow water as a refuge habitat for fish and crustaceans in non-vegetated estuaries: an example from Chesapeake Bay. Mar. Ecol. Prog. Ser. $99,1-16$

Sogard, S.M., 1989. Colonization of artificial seagrass by fishes and decapod crustacean: importance of proximity of natural eelgrass. J. Exp. Mar. Biol. Ecol. 133, 15-37.

Stoner, A.W., 1983. Distribution of fishes in seagrass meadows: role of macrophyte biomass and species composition. Fish. Bull. 81, 837-846.

Ter Morshuizen, L.D., Whitfield, A.K., 1994. The distribution of littoral fish associated with eelgrass Zostera capensis beds in the Kariega estuary, a southern African system with a reversed salinity gradient. S. Afr. J. Mar. Sci. 14, 95-105.

Underwood, A.J., 1997. Experiments in Ecology: their logical design and interpretation using analysis of variance. University Press, Cambridge.

Williams, A.H., Coen, L.D., Stoelting, M.S., 1990. Seasonal abundance, distribution, and habitat selection of juvenile Callinectes sapidus (Rathbun) in the northern Gulf of Mexico. J. Exp. Mar. Biol. Ecol. 137, 165-183.

Worthington, D.G., Ferrell, D.J., McNeill, S.E., Bell, J.D., 1992. Effects of the shoot density of seagrass on fish and decapodsare correlations evident over large spatial scales? Mar. Biol. 112, 139-146.

Young, P.C., 1981. Temporal changes in the vagile epibenthic fauna of two seagrass meadows (Zostera capricorni and Posidonia australis). Mar. Ecol. Prog. Ser. 5, 91-102. 